Збірник наукових праць. Серія: Галузеве машинобудування, будівництво

Academic journal. Series: Industrial Machine Building, Civil Engineering

http://journals.pntu.edu.ua/znp

https://doi.org/10.26906/znp.2018.51.1304

UDC 624.131

\title{
Peculiarities of structures inspection by the example of a three-chamber navigation lock in Zaporizhzhia city
}

\author{
Syvko Ivan ${ }^{1}$, Syvko Rudolf ${ }^{2}$, Selimov Anatoliy ${ }^{3}$, \\ Tytarenko Volodymyr ${ }^{4 *}$, Zharko Liudmyla ${ }^{5}$, Fesenko Oleg $^{6}$ \\ ${ }^{1}$ Zaporizhzhia branch of State Enterprise «State Research Institute of Building Constructions» \\ https://orcid.org/0000-0003-1369-8447 \\ ${ }^{2}$ Zaporizhzhia branch of State Enterprise «State Research Institute of Building Constructions» \\ https://orcid.org/0000-0002-7941-1376 \\ ${ }^{3}$ Zaporizhzhia branch of State Enterprise «State Research Institute of Building Constructions» \\ https://orcid.org/0000-0002-0983-7873 \\ ${ }_{5}^{4}$ State Enterprise «State Research Institute of Building Constructions https://orcid.org/0000-0001-9746-2399 \\ ${ }^{5}$ State Enterprise «State Research Institute of Building Constructions https://orcid.org/0000-0002-5966-1060 \\ ${ }^{6}$ State Enterprise «State Research Institute of Building Constructions https://orcid.org/0000-0001-8154-2239 \\ *Corresponding author:0679199507@ukr.net
}

Peculiarities of structures of hydro technical structures technical condition are considered. The problem concerning normative documentation on the inspection of hydraulic structures is considered, and the absence of standards for the inspection of this type structures is revealed. The issue of hydraulic structures inspection by the example of a three-chamber lockin Zaporizhzhia city is considered. The issue of the deformed state according to observations of past years are considered. The recommendations for the further exploitation, repair and completion of reconstruction of a three-chamber lockin Zaporizhzhia are given.

Keywords: hydrotechnical structure, inspection, evaluation of technical condition, safe exploitation

\section{Особливості обстеження гідротехнічних споруд на прикладі трика- мерного судноплавного шлюзу в м. Запоріжжя}

\author{
Сивко I.P. ${ }^{1}$, Сивко Р.І. ${ }^{2}$, Селімов А.М. ${ }^{3}$, Титаренко В.А. ${ }^{4 *}$, Жарко Л.О. ${ }^{5}$, Фесенко О.А. ${ }^{6}$ \\ 1,2,3 Запорізьке відділення ДП «Державний науково-дослідний інститут будівельних конструкцій» \\ 4,5,6 ДП «Державний науково-дослідний інститут будівельних конструкцій», м. Київ \\ *Адреса для листування: 0679199507@ukr.net
}

\begin{abstract}
Розглянуто питання обстеження з визначенням технічного стану будівельних конструкцій гідротехнічних споруд. Указано основні причини виконання обстеження будівель та споруд. Наведено деякі приклади будівельних об'єктів, на яких виникли аварійні ситуації за останні декілька років. Розглянуто питання щодо нормативної документації $з$ питання обстеження гідротехнічних споруд, виявлено відсутність діючих нормативів з обстеження споруд такого типу. Розглянуто питання обстеження гідротехнічних споруд на прикладі трикамерного судноплавного шлюзу в м. Запоріжжя. Проаналізовано життєвий цикл гідротехнічної споруди (зведення, експлуатація, відбудова, реконструкція). Наведено результати натурних дослідженнь міцності матеріалів конструкцій. Для визначення міцності бетонних конструкцій об'єкта обстеження було відібрано зразки бетону (зі стіни 1-ї камери шлюзу, днища 2-ї камери шлюзу, стіни 3-ї голови шлюзу). Виконано випробування зразків, за яким було встановлено міцність відібраних зразків на стиск. Визначено складні місця з діагностування технічного стану гідротехнічних споруд. Доведено, що якісною характеристикою технічного стану споруди є його деформований стан для оцінювання стану трикамерного шлюзу. Розглянуто питання деформованого стану за даними спостережень минулих років, наведено графіки деформацій та коливання рівня грунтових вод. Запропоновано рекомендації з подальшої експлуатації, ремонту та завершення реконструкції трикамерного судноплавного шлюзу в м. Запоріжжя.
\end{abstract}

Ключові слова: гідротехнічна споруда, обстеження, оцінка технічного стану, безпечна експлуатація 
Introduction. Hydraulic structures and any engineering structure inspection is performed to determine object technical condition and its individual elements. The main types and reasons for the inspection are:

a) planned inspection has been performed before the design and execution of works on reconstruction, overhaul or restoration;

b) scheduled periodic inspections have been performed according to the established procedure and the term;

c) unscheduled inspections - performed at the inspected of strains, defects and injuries, in order to determine the causes and their elimination, as well as the restoration of damaged structures.

Analysis of recent sources of research and publications. Hydrotechnical structures represent potentially dangerous objects of failure which can lead to large losses (human, economic, environmental), therefore the question of determining these objects technical state is currently quite acute. Permanent occurrence of emergencies on different types of construction sites in the country are given such as:

- fall of a metal roof with an area of $2400 \mathrm{~m}^{2}$ in early March 2018 at the shop of «ArsilorMittal Kryvyi Rih»;

- destruction of a new elevator near the city of Nikolaev in August 2017;

- fall of the bridge construction part

in Kyiv in February 2017, and so on.

Thus, the inspection of buildings and structures, especially hydrotechnical ones, with increased danger, is one of the most important construction projects in Ukraine and abroad $[9,10]$

At present new regulatory documents on inspection $[2,4]$ have been developed and are in implemented in the construction industry, and the evaluation of buildings and structures technical condition for civil and industrial use.

Highlighting of unsolved aspects of the problem. In this regard, the hydrotechnical structures do not have normative documents on technical condition inspection and determination; at present, only order No. 252, December 19, 1995 of the State Committee of
Ukraine for Urban Development and Architecture [6] exists. Thus, the development and implementation of normative documents on inspection of hydraulic structures is extremely relevant, considering these objects resposibility degree.

Problem statement. To consider the inspection of hydraulic structures with the definition of object technical condition and its individual elements, for example, a three-chamber locklocated in the city of Zaporizhzhia.

Main material and results. The question of hydrotechnical structure inspection is considered on the real object of a three-chamber lock in Zaporozhye. The general type of gateway construction is shown in Figure 1.

In 2017 the specialists of Zaporizhzhia branch of State Enterprise «State Research Institute of Building Structures» and State Enterprise «State Research Institute of Building Structures», with the involvement of a professional executor (construction and hydrotechnical engineer) performed works on visual and instrumental inspection of this hydraulic engineering works. The purpose of the work was to inspect the construction structures, evaluate their technical condition and develop recommendations for their repair and completion of reconstruction, determine structures materials strength on selected samples, analysis of object deformed state according to observations during past years. Considering the lack of normative documents with the technical condition for such buildings, during the inspection norms for civil and industrial construction objects are used $[2,4]$. The three-chamber lockis an integral part of the hydraulic unit in the gravitational dam of two hydroelectric power stations and two gateways (three-chamber (inspected, not exploited) and single-chamber (exploited)). The inspected object basis are the rocks represented by granites, which have a cracked structure. It should be noticed that the drainage tunnels of the new gateway pass under a three-chamber gateway. Thus, the inspection object can be attributed to the structures located in complex engineering-geological conditions. [1].

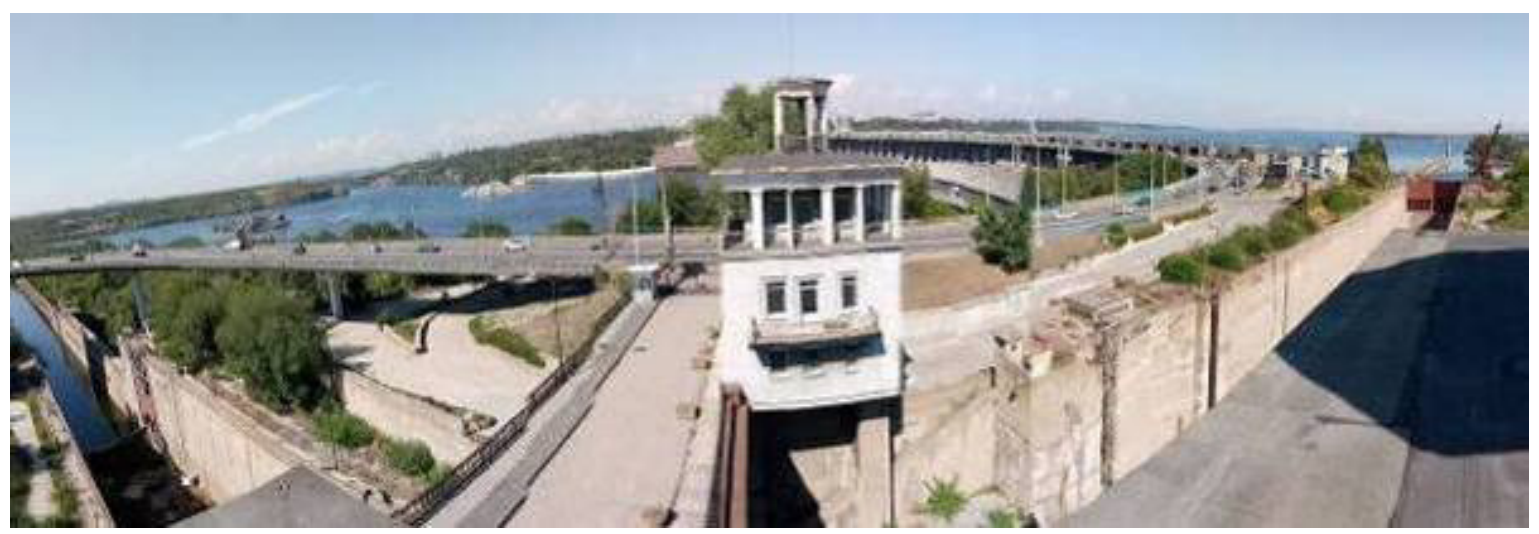

Figure 1 - General view of a three-chamber navigation lock in Zaporizhzhia city 
The life cycle of this object can be divided into five stages:

- errection and putting into exploitation (1927-32, 1934 year) (Fig. 2);

- exploitation (1934 - 1941 year);

- post-war reconstruction (1945 - 1950 year);

- exploitation (1950 - 1993 year);

- reconstruction (1993 - 2018 year).

In general, the inspection object can be divided into the following construction elements:

- wharf and upper and lower canals;

- the heads of the lock (four heads);

- lock chambers (three chambers);

- culverts (pass from the upper underwater channel through the heads and bottom of chambers to the lower underwater channel);

- gate shafts (located in the heads of gateways by two on each head);

- premises for ships kinetic energy absorbers mechanisms (located in the first and second lock heads, two on each head)

- premises for gates control mechanisms (located two on each head);
- turning bridge premises (located on land lock wall of the first chamber in the first head);

- drainage path from the river side of 3 chamber;

- control panel towers (located at the second chamber of the lock on the river and land sides);

- unitized transformer substation building (erected near the tower of land side control);

- cable channels (arranged along the structure on both sides).

- to determine the concrete structures strength, the following samples were taken from the following structures:

- wall of the 1st lock chamber - 4 batches of 3 samples $\varnothing 94 \mathrm{~mm}$ (designation K1.1-K1.4);

- the bottom of the $2_{\text {nd }}$ chamber of the lock -2 batches of 3 samples $\varnothing 94 \mathrm{~mm}$ (designation K2.1K2.2);

- the walls of the $3_{\text {rd }}$ head of the lock -2 batches of 3 samples $\varnothing 94 \mathrm{~mm}$ (designation Г3.1-Г3.2).

A general view of structure construction with sampling areas is shown in Figure 3. After sampling, the samples were tested, and testing results are given in Table 1.
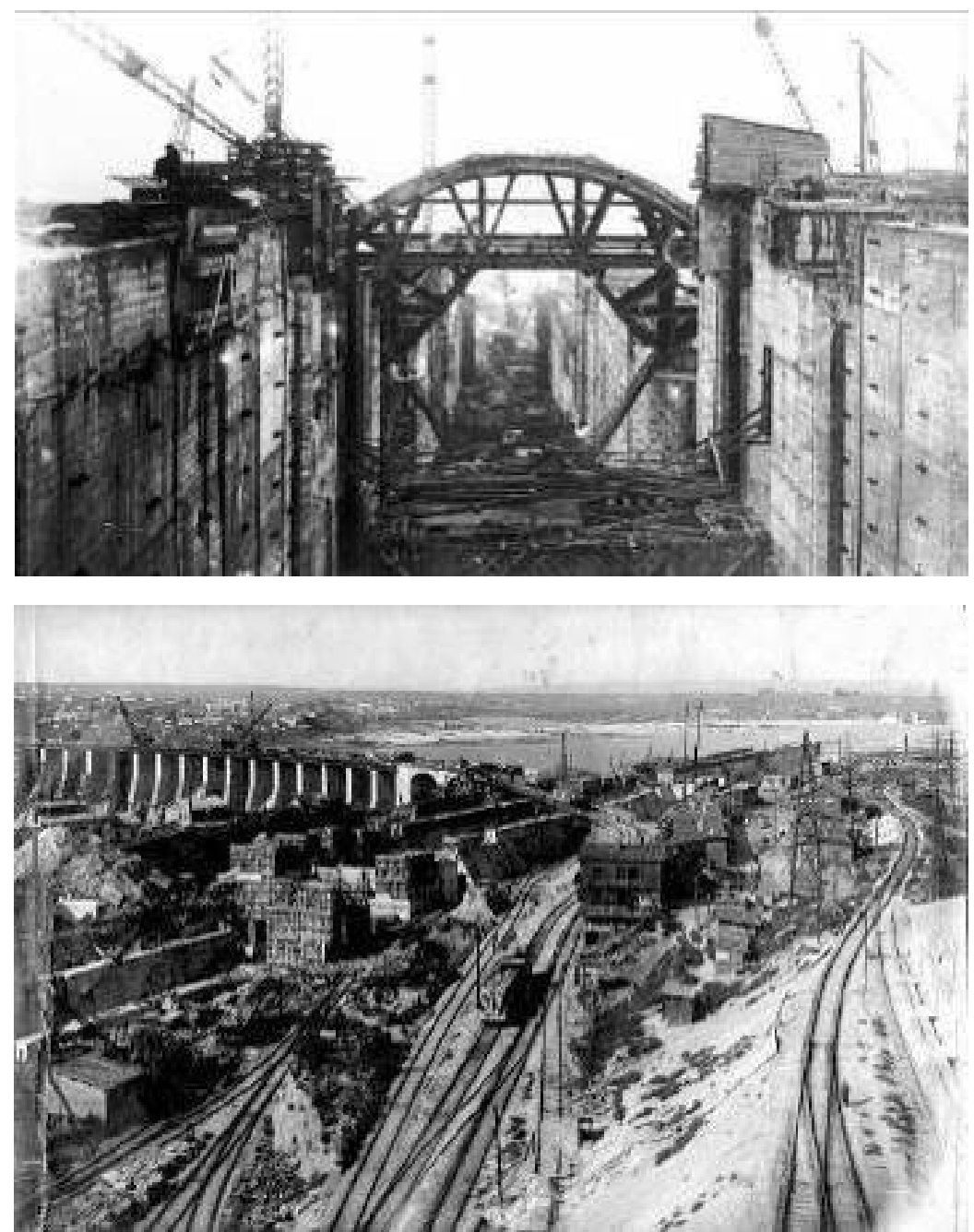

Figure 2 - General view of a three-chamber navigation lock in Zaporizhzhia city 

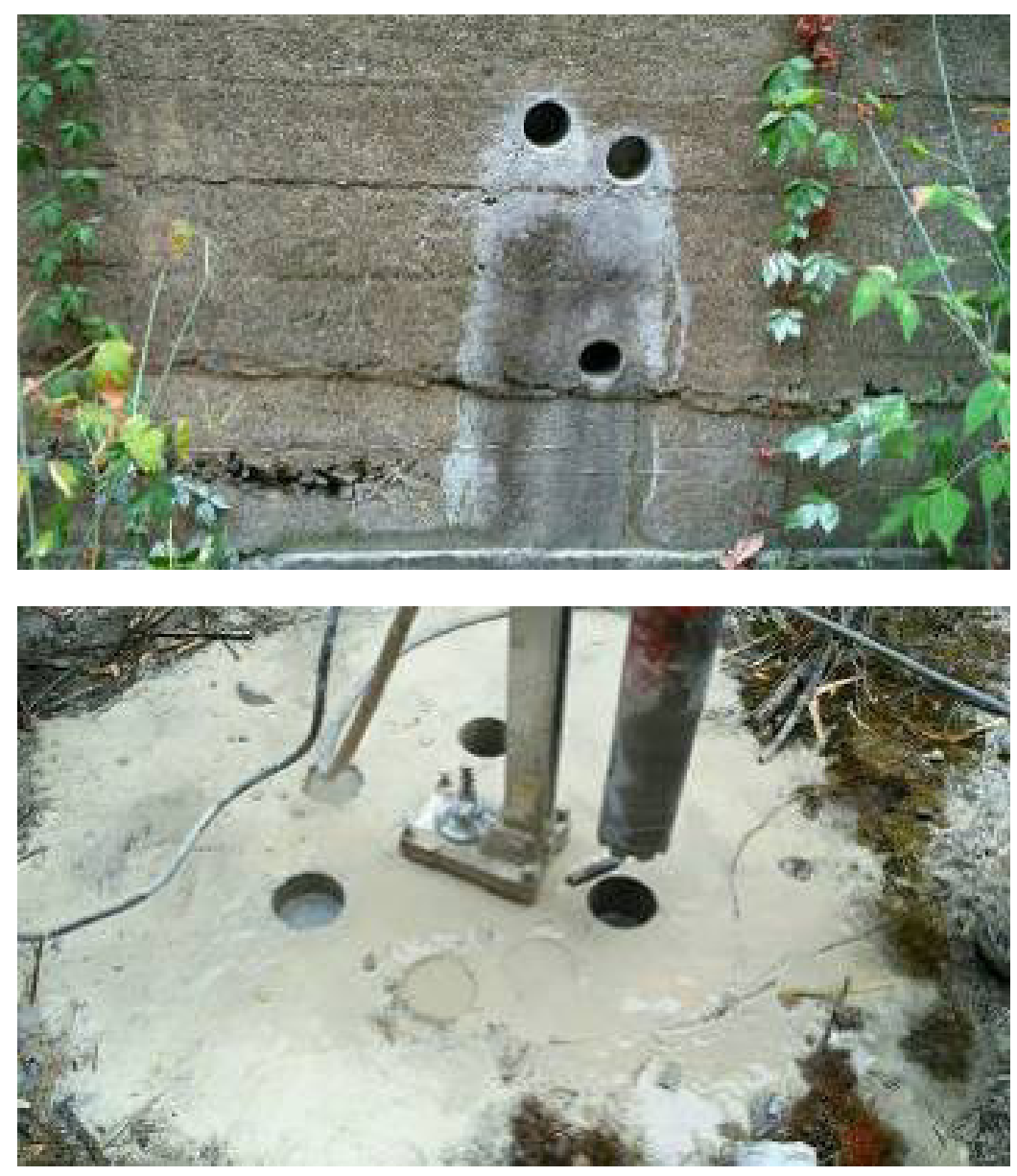

Figure 3 - General view of construction site with sampling area

Table 1 - The results of concrete cores samples compression tests

\begin{tabular}{|c|c|c|c|c|c|c|c|c|c|c|c|c|}
\hline \multirow{3}{*}{ 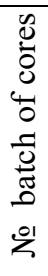 } & \multirow{3}{*}{ 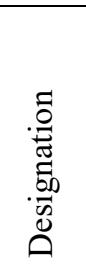 } & \multirow{3}{*}{ 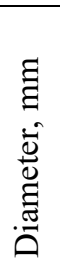 } & \multirow{3}{*}{ 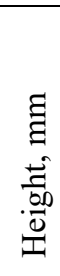 } & \multirow{3}{*}{$\eta 1$} & \multirow{3}{*}{ 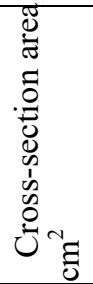 } & \multirow{2}{*}{\multicolumn{2}{|c|}{ Destructive load }} & \multirow{3}{*}{$\alpha$} & \multicolumn{4}{|c|}{$\begin{array}{l}\text { Compression strength, given } \\
\text { to the base size }\end{array}$} \\
\hline & & & & & & & & & \multicolumn{2}{|c|}{ one sample } & \multicolumn{2}{|c|}{$\begin{array}{c}\text { average } \\
\text { of } 2 \text { samples the } \\
\text { largest on strength }\end{array}$} \\
\hline & & & & & & $\mathrm{kN}$ & $\mathrm{kgf}$ & & $\mathrm{MPa}$ & $\mathrm{kgf} / \mathrm{cm}^{2}$ & $\mathrm{MPa}$ & $\mathrm{kgf} / \mathrm{cm}^{2}$ \\
\hline 1 & 2 & 3 & 4 & 5 & 6 & 7 & 8 & 9 & 10 & 11 & 12 & 13 \\
\hline \multirow{3}{*}{1} & \multirow{3}{*}{ K1.1 } & 94 & 82 & 0.96 & 69.36 & 492.30 & 50200 & 0.88 & 59.98 & 611.41 & \multirow{3}{*}{58.21} & \multirow{3}{*}{593.34} \\
\hline & & 94 & 83 & 0.96 & 69.36 & 455.04 & 46400 & 0.80 & 50.40 & 513.75 & & \\
\hline & & 94 & 105 & 1.04 & 69.36 & 427.58 & 43600 & 0.88 & 56.43 & 575.28 & & \\
\hline \multirow{3}{*}{2} & \multirow{3}{*}{ K1.2 } & 94 & 85 & 0.96 & 69.36 & 411.89 & 42000 & 0.88 & 50.18 & 511.54 & \multirow{3}{*}{47.49} & \multirow{3}{*}{484.13} \\
\hline & & 94 & 90 & 1.00 & 69.36 & 323.62 & 33000 & 0.96 & 44.81 & 456.73 & & \\
\hline & & 94 & 87 & 0.96 & 69.36 & 355.01 & 36200 & 0.88 & 43.25 & 440.90 & & \\
\hline \multirow{3}{*}{3} & \multirow{3}{*}{ K1.3 } & 94 & 86 & 0.96 & 69.36 & 415.81 & 42400 & 0.88 & 50.66 & 516.41 & \multirow{3}{*}{52.71} & \multirow{3}{*}{537.32} \\
\hline & & 94 & 97 & 1.00 & 69.36 & 431.50 & 44000 & 0.88 & 54.76 & 558.23 & & \\
\hline & & 94 & 95 & 1.00 & 69.36 & 376.58 & 38400 & 0.88 & 47.79 & 487.18 & & \\
\hline
\end{tabular}


According to the tests, significant indicators of concrete selected samples strength in compression were identified.

When performing inspection work, a number of defects and damage was detected, which totality determined the technical condition of object construction structures:

- wharf and upper and lower canals; - satisfactory (category 2 [2]) with areas unsuitable for normal exploitation (category 3 [2]);

- the heads of the lock - satisfactory (category 2 [2]) from the pre-emergency area (stoplogs) (category 3 $4[2])$

- lock chambers - satisfactory (category 2 [2]) with areas unsuitable for normal exploitation (category 3 [2]);

- cuverts - satisfactory (category 2 [2]) with areas unsuitable for exploitation (absorber) (category 3 [2]);

- gate shafts - satisfactory (category 2 [2]) with in pre-emergency areas (staircases) (category $3-4$ $[2,4])$

- premises of the mechanisms of the kinetic energy absorbers of ships during the invasion - unsuitable for normal exploitation (category 3 [2]) with emergency (front cover) sections (category $3-4$ [2]);

- the premises of the mechanisms of kinetic energy absorbers of ships during the invasion - unsuitable for normal exploitation (category 3 [2]) with preemergency areas (reinforced concrete floor) (category $3-4[2])$
- turning bridge premises - unsuitable for normal exploitation (category 3 [2]);

- the drainage path from the river side consisting of 3 cameras - unsuitable for normal operation (category $3[2])$;

- control panel towers - satisfactory (category 2 [2]) with areas unsuitable for normal exploitation (category 3 [2]);

- unitized transformer substation building - satisfactory (2 category [2]);

- cable channels - unsuitable for normal exploitation (category 3 [2]).

The qualitative characteristic of structure technical condition is its deformed state. Considering that inspection object belongs to hydrotechnical category, significant influence on it is done by filtration processes in soil in-situ, with which it works along the line of hydraulic unit pressure front.

The customer provided with observational data on structure deformations, groundwater fluctuations, as well as deformations of adjacent sections of lock chamber walls. For optimal interpretation of the provided observational data, dependency graphs were constructed.

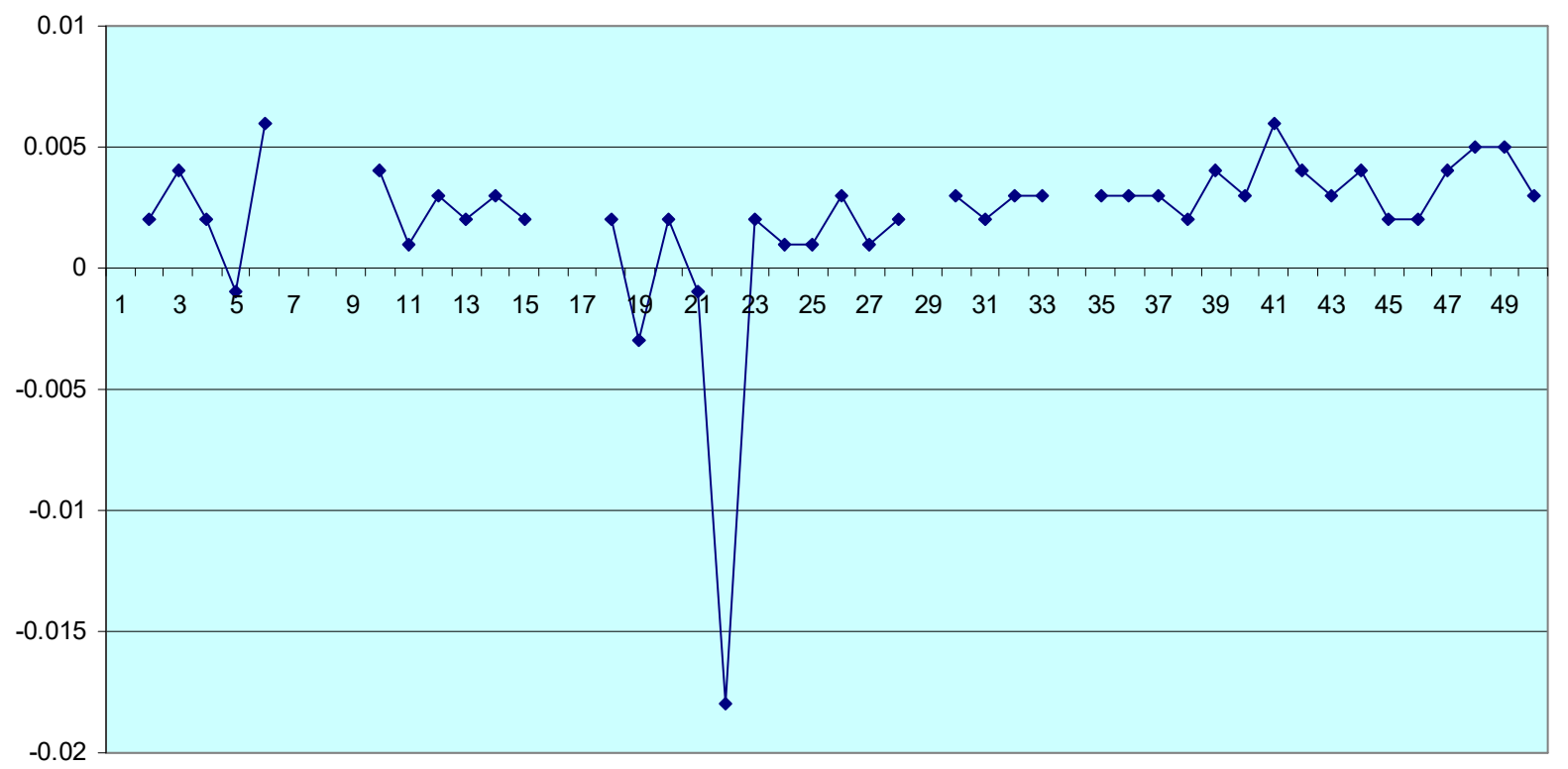

Figure 4 - Graph of deformation control benchmark change of three-chamber lock during the period from 1975 to 1985

(on the graph $1 \ldots 50$ - mark numbers $0.01 \ldots 0.02$ - change of marks in [m], breaks of the chart in the places of marks destruction) 


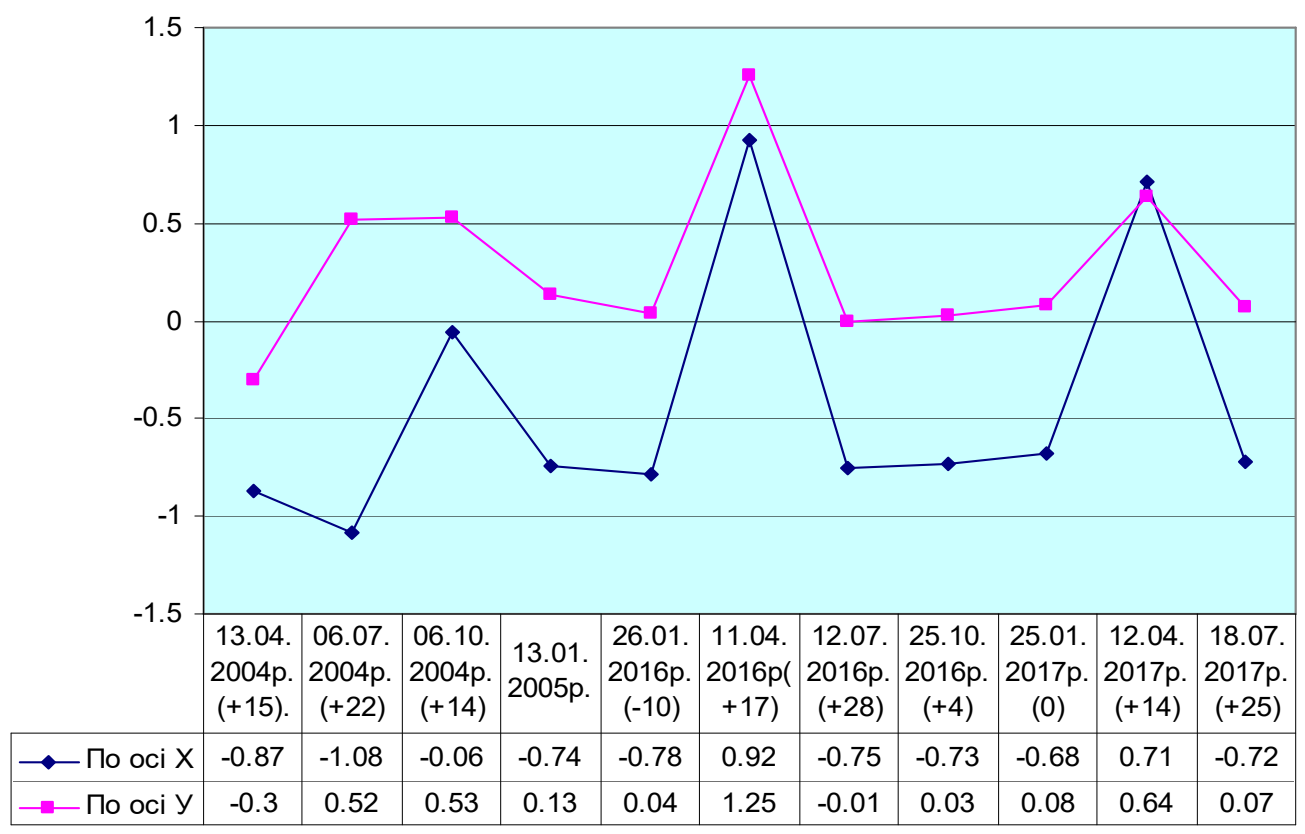

Figure 5 - Deformation graph along the joint 2-04

(on the graph: $1.5 \ldots-3$ - step value in [mm];

13.04.2004 - date of data readout; $+28 \ldots 10$ - outdoor air temperature)

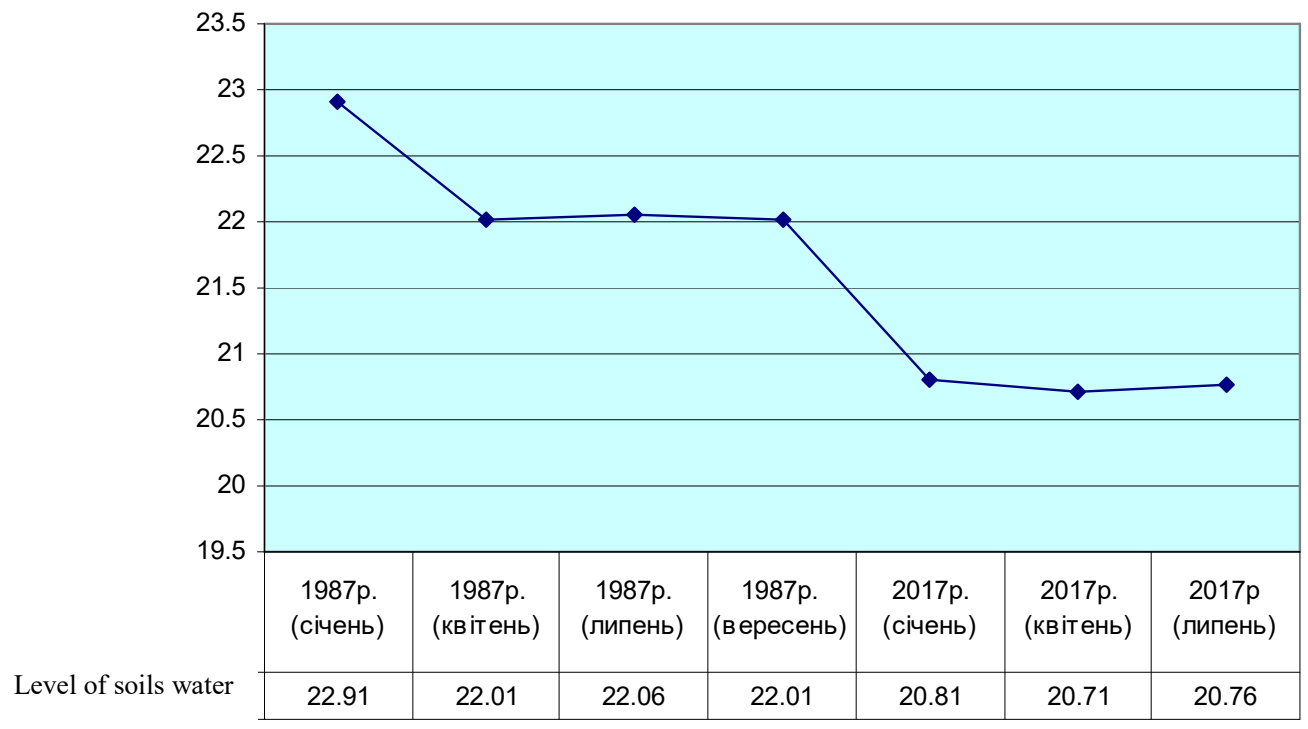

Figure 6 - Graph of groundwater level change by piezometers TR-3 (on the graph: 23.5 ... 19.5 - water level mark in [m];

1987 ... 2017 - date of data readout)

For object deformed state evaluation, observation data analysisof object deformations and the fluctuations of groundwater has been carried out, which results are the following:

- the leveling data given by customer do not reflect inspected object deformed state;

- unidirectional deformations of adjacent sections during the observation period have not been recorded; the revealed increase of the measured values basically indicates concrete anays temperature deformation;

- for the period from 1987 - 2017 ground water level has decreased, which is due to the stopping of three-chamber lock exploitation and new depression curve formation. 
The results of the inspection provided recommendations for further exploitation and the possibility of completing the reconstruction started in 1993, considering existing normative documents $[3,5,7,8]$ :

1). Reconstruction work should be carried out after defects and damage elimination recorded during the examination.

2 ). The work should be conducted on a separate project, developed by a specialized organization in the presence of operational plan.

3 ). The project should provide for section of work in-depth monitoring hydraulic engineering state required in accordance with [5].

4). When carrying out the work it is necessary to conduct thorough supervision of the author with the compilation of all necessary executive documentation.

$5)$. To conduct scientific and technical support of works in accordance with the requirements $[3,7]$.

6). After the reconstruction (before exploitation) and lock chambers filling, perform a detailed inspection and evaluation of drainage system work with compilation of relevant acts and report on investigation results.

7). To establish permanent geodetic control of the construction before reconstruction, during reconstruction, and after commissioning. To do this, it is necessary to develop a geodetic monitoring program.

8). After reconstruction, before exploitation, object detailed inspection has been performed in accordance with the requirements [5].

9). The structure should be equipped with an automated system for monitoring the technical condition in accordance with current standarts requirements [3].

Conclusions. The issue of hydraulic structures inspection on the example of a three-chamber navigation lock in Zaporizhzhia city is considered. Problem (lack of regulatory documents) in the inspection of hydraulic structures is revealed. The analysis of observation data for three-chamber gateway structure deformed state is given. Difficult places to diagnose the technical condition of such structures are determined. Building structures and object technical condition is given. According to the performed research, recommendations for further exploitation and reconstruction completion possibility are given. Based on the recommendations, project was developed to restore damaged structures and complete the reconstruction of a threechamber navigation lock in Zaporizhzhia.

\section{References}

1. ДБН В.1.1-45:2017. (2017). Будівлі і споруди в складних інженерно-геологічних умовах. Загальні положення. Київ: Мінрегіонбуд України, Укрархбудінформ.

2. ДСТУ-НБВ.1.2-18:2016. (2017). Настанова щодо обстеження будівель і споруд для визначення та оиінки ї технічного стану. Київ: ДП УкрНДНЦ.

3. ДБН В.1.2-14-2008. (2009). Загальні принциии забезпечення надійності та конструктивної безпеки будівель, споруд, будівельних конструкцій та основ. Київ: Мінрегіонбуд України, Укрархбудінформ.

4. ДСТУ Б.В.2.6-210:2016. (2017). Оиінка технічного стану сталевих будівельних конструкиій, щзо експлуатуються. Київ: Мінрегіонбуд України, Укрархбудінформ.

5. ДБН В.2.4-3:2010. (2011). Гідротехнічні споруди. Основні положення. Київ: Мінрегіонбуд України, Укрархбудінформ.

6. Наказ № 252 [1995.12.21]. (1995). Про затвердження Методики обстеження і паспортизаиії гідротехнічних споруд систем гідравлічного вилучення та складування промислових відходів. Київ: Держбуд України.

7. ДБН В.1.2-5:2007. (2008). Науково-технічний супровід будівельних об'єктів. Київ: Мінрегіонбуд України, Укрархбудінформ.

8. ДБН В.2.6-98:2009. (2011). Бетонні та залізобетонні конструкції. Основні положення. Київ: Мінрегіонбуд України, Укрархбудінформ.

9. Fell R., MacGregor, P., Stapledon, D., Bell, G. \&

Foster, M. (2015). Geotechnical Engineering of Dams. London: CRC Press. eBook ISBN 9780203387313

10. FEMA (2006). Conduits through Embankment Dams. Best practices for design, construction, problem identification and evaluation, inspection, maintenance, renovation and repair. US Federal Emergency Agency. 